\title{
Dynamics of Nitrogen Transformation and Removal in a Pilot High Rate Pond
}

\author{
Aloyce W. Mayo, Emmanuel E. Hanai \\ Department of Water Resources Engineering, University of Dar es Salaam, Dar es Salaam, Tanzania \\ Email: aloyce.mayo@yahoo.com
}

Received 20 January 2014; revised 21 February 2014; accepted 22 March 2014

Copyright (C) 2014 by authors and Scientific Research Publishing Inc.

This work is licensed under the Creative Commons Attribution International License (CC BY). http://creativecommons.org/licenses/by/4.0/

\section{Open Access}

\section{Abstract}

The transformation and removal of nitrogen was studied in a pilot high rate pond with a surface area of $10.2 \mathrm{~m}^{2}$ and water depth of $60 \mathrm{~cm}$. The pilot unit received wastewater from an existing field scale primary facultative pond at the University of Dar es Salaam. Wastewater samples were collected from the influent and effluent of high rate pond and were analyzed for physical-chemical parameters in the laboratory and in situ. An appropriate model complexity was selected, from which a conceptual model was then developed to model various processes in the system using STELLA 6.0.1 software. The study demonstrated that dominant nitrogen transformation processes in HRP were nitrification and denitrification, which transformed 0.95 and $0.87 \mathrm{gN} / \mathrm{m}^{2} \cdot \mathrm{d}$, respectively. These were followed by mineralization $\left(0.37 \mathrm{gN} / \mathrm{m}^{2} \cdot \mathrm{d}\right)$, ammonia uptake by microorganisms $\left(0.34 \mathrm{gN} / \mathrm{m}^{2} \cdot \mathrm{d}\right)$, volatilization $\left(0.30 \mathrm{gN} / \mathrm{m}^{2} \cdot \mathrm{d}\right)$, sedimentation $\left(0.24 \mathrm{gN} / \mathrm{m}^{2} \cdot \mathrm{d}\right)$, and regeneration $\left(0.15 \mathrm{gN} / \mathrm{m}^{2} \cdot \mathrm{d}\right)$. Uptake of nitrate was not observed because of microorganisms preference for ammonia, which was abundant in the pond. The major nitrogen transformation mechanisms in high rate pond were denitrification, net sedimentation and volatilization, which accounted for $69.1 \%, 7.1 \%$ and $23.8 \%$ of the total permanent removal mechanisms of nitrogen in High Rate Pond.

\section{Keywords}

High Rate Ponds, Nitrification, Denitrification, Nitrogen Transformation, Nitrogen Removal

\section{Introduction}

Waste stabilization ponds have found wide application in tropical climates [1] [2] although their application in temperate climate is not uncommon [3]. However, in cold climates, wastewater is applied at very low hydraulic loading rates [4] and low organic loading rates of less than $60 \mathrm{kgBOD}_{5} / \mathrm{ha} / \mathrm{d}$ [5]. Waste stabilization ponds are 
commonly used for treatment of wastewater from domestic, industrial and agricultural sources [6]-[9] with an objective of reduction of organic matter [2] [10] [12], pathogenic organisms [13]-[15] and nutrients particularly nitrogen [3] [6] [16].

Waste stabilization ponds have numerous advantages over other biological wastewater treatment systems. These advantages include reduction of pathogenic microorganisms without addition of chemicals; low construction, operation and maintenance costs, low sensitivity to hydraulic and organic shock loads, minimum or no mechanical equipment are required for their operation and low requirement of external source of energy [13] [17] [18]. Unfortunately, ponds require large area of land for their construction and release large amount of biomass in the effluent [18]-[20]. In an effort to reduce land requirement more efficient systems such as high rate ponds, which can improve reaction rates substantially, are desired.

The release of nitrogen-rich wastewater effluents into receiving rivers and its long-term adverse effects on the environment and human health are of great concern [21]. Increased levels of nitrogen in receiving water bodies have lead to eutrophication that disturbs aquatic ecosystems [22], difficulties in water treatment and serious health problems especially to infants [9] [23]. Nitrite is known to oxidize the iron (II) and cause methamoglobinaemia, which binds oxygen less effectively than normal haemoglobin. Methamoglobinaemia, also known as blue baby disease, can lead to diarrhea, vomiting, and in extreme cases even death in young children [24]. On the other side, ammonia can deplete the dissolved oxygen in water and is extremely toxic to fish and many other aquatic organisms [25] and can cause shifts in microbial community structure and altering aquatic nitrogen cycle [26]. Consequently, fragile plants and animal species can be replaced by nitrogen-responsive species, which may lead to disruption or even extinction of the ecosystem [23].

Nitrogen transformation is adequately detailed in literature, but removal mechanisms in high rate ponds are not well understood. Previous studies on nitrogen removal have demonstrated fluctuations, variability and inconsistencies, because of different media, plants and environmental conditions [27]. This erratic removal pattern has made it difficult to optimize nitrogen removal in high rate ponds, which undermines the prospects of providing small communities with cheap and appropriate wastewater treatment technologies among other technologies that can remove nitrogen. For this reason the use of ponds is beneficial, especially for small communities that cannot afford such expensive conventional treatment systems. Different researchers have reported on the transformation and removal of nitrogen in waste stabilization ponds. This research therefore was focused on the study of biological nitrogen removal in a high rate pond with a view of establishing their effectiveness on transformation and removal of nitrogen and developing a mathematical model that simulates the transformation of nitrogen in such systems.

\section{Methods and Materials}

\subsection{Pilot Plant}

The pilot plant for this study is located downstream of a primary facultative pond treating wastewater from the University of Dar es Salaam (UDSM) community. The scheme is located at latitude $6^{\circ} 48^{\prime} \mathrm{S}$ and longitude $39^{\circ} 13^{\prime} \mathrm{E}$, where the mean monthly air temperature of the site varies between $23^{\circ} \mathrm{C}$ and $28^{\circ} \mathrm{C}$ with a mean value of $26^{\circ} \mathrm{C}$ [28]. The waste stabilization pond system receives wastewater of largely domestic characteristics; with some proportion of chemical wastes from the university dispensary, laboratories and workshops through a 20 $\mathrm{mm}$ diameter pipe. This unit, whose length and width were $9.2 \mathrm{~m}$ and $1.0 \mathrm{~m}$, respectively was designed to receive $1.2 \mathrm{~m}^{3} / \mathrm{d}$ of pre-treated wastewater, which provides a retention period of about 5 days. Effluent from the water hyacinth wetland was discharged into a receiving channel for final disposal (Figure 1).

\subsection{Sampling and Examination of Samples}

Wastewater samples for laboratory analyses were collected in clean $250 \mathrm{ml}$ sampling bottles from the influent and effluent HRP between 10.00 a.m. and 10.30 a.m. at interval of one day. The collected samples were examined within 2 hours in the UDSM water quality laboratory. Samples were analyzed for Ammonium nitrogen $\left(\mathrm{NH}_{4}^{+}-\mathrm{N}\right)$, total Kjeldahl nitrogen (TKN) and nitrate nitrogen $\left(\mathrm{NO}_{3}^{-}-\mathrm{N}\right)$ in the laboratory. Dissolved oxygen (DO), $\mathrm{pH}$ and water temperature were measured in situ during sampling. Temperature and $\mathrm{pH}$ were measured using a pH meter with a temperature electrode (Metrohm pH meter, model 704). Dissolved oxygen concentration was measured using a digital DO meter (YSI DO meter, model 50B). Nitrate was analyzed by cadmium re- 


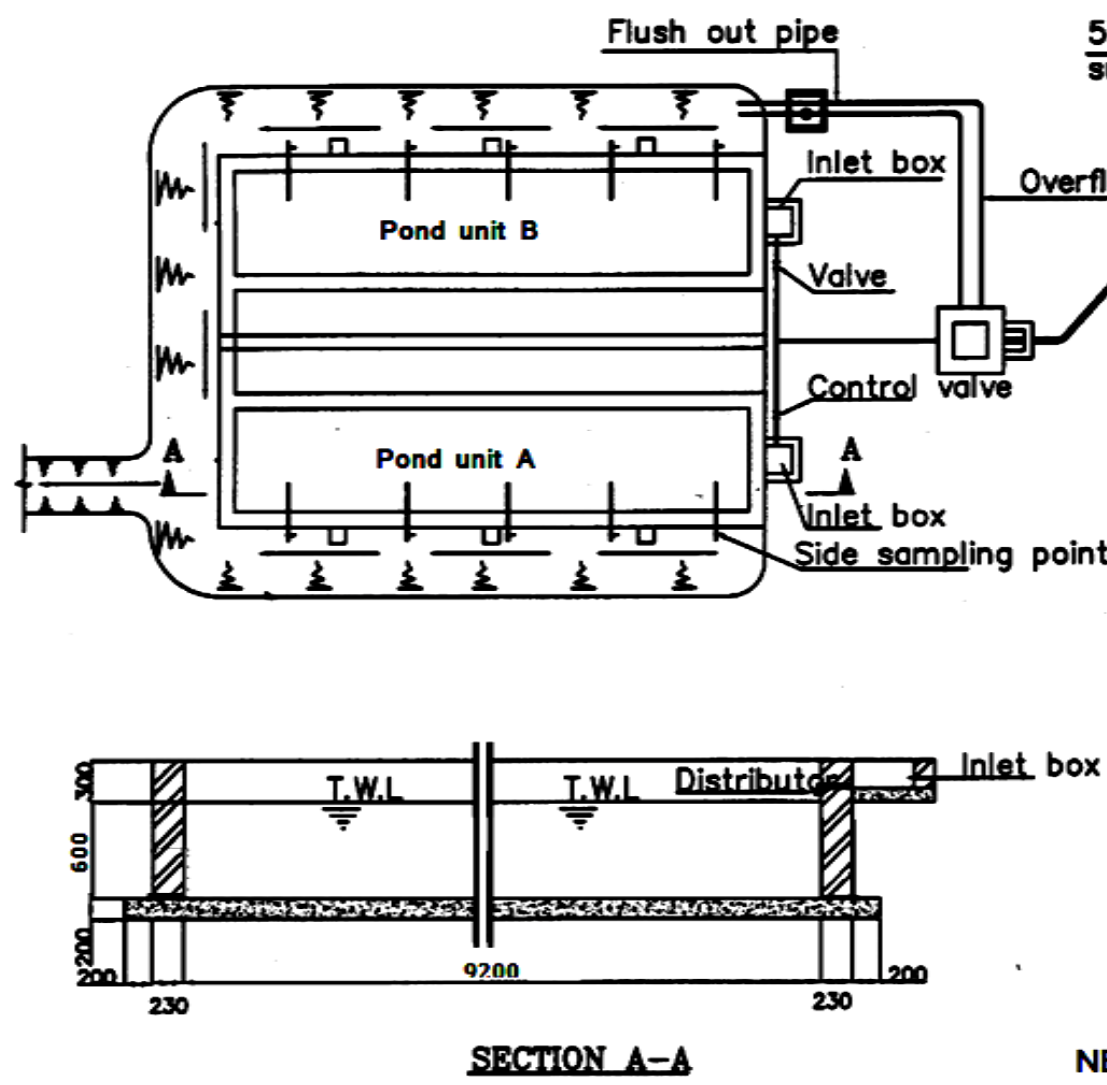

NB: Dimensions are in millimetres

Figure 1. Layout of experimental ponds.

duction method; ammonia was extracted by distillation followed by titration with $0.02 \mathrm{~N}$ sulphuric acid. TKN was determined using the semi micro-Kjeldahl method in accordance with Standard Methods [29].

\subsection{Analysis of Data}

A conceptual model was developed in which equations of various processes were entered into STELLA 6.0.1 software that was used to run the model. Nitrogen forms considered were organic nitrogen, ammonia nitrogen and nitrate-nitrogen, which were taken as state variables within the system. The transformation mechanisms considered in the models were mineralization, nitrification, denitrification, sedimentation, ammonia regeneration, uptake of inorganic nitrogen (ammonia and nitrates) by algae and bacteria, and ammonia volatilization. Appropriate model complexity was selected to avoid the complicated complexity and mathematical equations were used to link the relationship between the state variables and forcing functions. Equations defining transformation processes were entered into the model, which was then calibrated using the observed data versus model simulations. The model was then run while obeying the principle of conservation of mass, which was used to ensure mass balance in the system until the most efficient model results were obtained.

Figure 2 shows the conceptual model that encompasses important state variables included in this study. The model shows the flow of material from one state variable to another or in and out of the system through nitrogen transformation and removal mechanisms. A complete materials balance including all substances produced, consumed in biochemical reactions, inflows, outflows, accumulations and depletion was used. The system was assumed to be continuous completely mixed flow type and water loss through evaporation and seepage was insignificant. Equation (1) illustrates the general symbolic mass balance equation used as the basis for developing the various equations in the model.

$$
V \frac{\mathrm{d} C}{\mathrm{~d} t}=V \sum_{j=i}^{m}\left(r_{c}\right)_{j}+Q_{i} C_{i}-Q_{o} C_{o}
$$




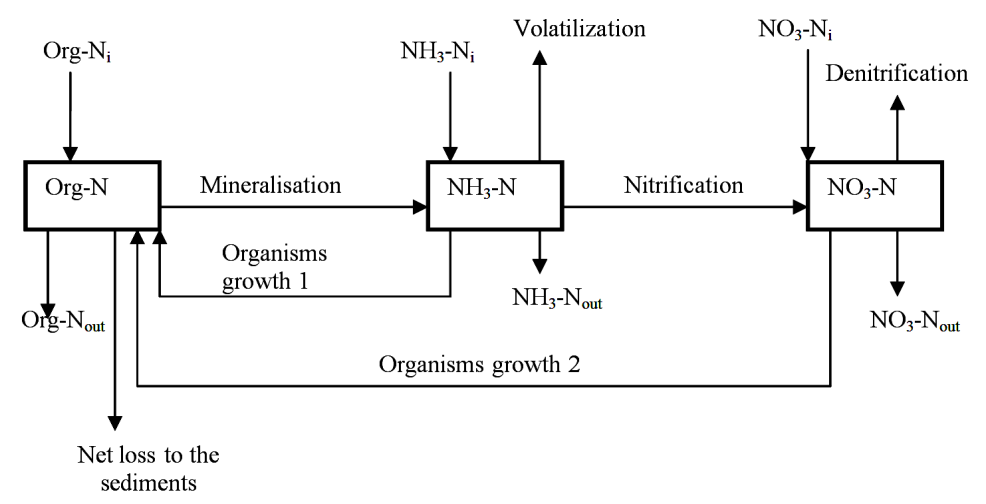

Figure 2. Nitrogen transformation and removal in HRP.

where $C_{o}=$ effluent concentration $\left(\mathrm{g} / \mathrm{m}^{3}\right), V=$ reactor volume $\left(\mathrm{m}^{3}\right), r_{c}=$ volumetric reaction rate $\left(\mathrm{g} / \mathrm{m}^{3} \cdot\right.$ day $), C_{i}=$ influent concentration $\left(\mathrm{g} / \mathrm{m}^{3}\right), m=$ number of reactions that involve the substance, $V(\mathrm{~d} C / \mathrm{d} t)=$ volumetric rate of change of substance in the reactor $\left(\mathrm{g} /\right.$ day), $Q_{i}=$ influent flow rate $\left(\mathrm{m}^{3} /\right.$ day), $Q_{o}=$ effluent flow rate $\left(\mathrm{m}^{3} /\right.$ day).

Mass balance equations for organic nitrogen, ammonia-nitrogen, and nitrate-nitrogen in high rate pond (HRP) are expressed in accordance with Equations (2)-(4), respectively.

$$
\frac{\mathrm{d}\left(\mathrm{Org} \_\mathrm{N}\right)}{\mathrm{d} t}=\frac{Q_{i}}{A}\left(\mathrm{Org} \_\mathrm{N}\right)_{i}-\frac{Q_{e}}{A}\left(\mathrm{Org} \_\mathrm{N}\right)+r_{g 1}+r_{g 2}-r_{m}-r_{s}
$$

where $r_{g 1}=$ rate of ammonia uptake by micro-organisms for growth $\left(\mathrm{g} / \mathrm{m}^{2} \cdot \mathrm{d}\right), r_{g 2}=$ rate of nitrate uptake by micro organisms for growth $\left(\mathrm{g} / \mathrm{m}^{2} \cdot \mathrm{d}\right), r_{m}=$ mineralization rate of organic nitrogen $\left(\mathrm{g} / \mathrm{m}^{2} \cdot \mathrm{d}\right), r_{s}=$ settling rate of organic nitrogen in water $\left(\mathrm{g} / \mathrm{m}^{2} \cdot \mathrm{d}\right)$. Mineralization process was modeled using first order kinetics with respect to organic nitrogen concentration in accordance with Martin and Reddy [30].

Nitrification process was limited by the activity of nitrosomonas bacteria [31], because nitrite concentrations were always low. Therefore nitrite production and removal were not taken into consideration. In general nitrification process is influenced by temperature, DO and $\mathrm{pH}$. Therefore the rates shown in Equation (3) were accordingly modified to take into account the influence of these forcing functions in accordance with Mayo and Bigambo [32].

$$
\frac{\mathrm{d}\left(\mathrm{NH}_{3 \_} \mathrm{N}\right)}{\mathrm{d} t}=\frac{Q_{i}}{A}\left(\mathrm{NH}_{3-} \mathrm{N}\right)_{i}-\frac{Q_{e}}{A}\left(\mathrm{NH}_{3-} \mathrm{N}\right)-r_{n}-r_{v}-r_{g 1}+r_{r e g}+r_{m}
$$

where $r_{n}=$ rate of nitrification of ammonia $\left(\mathrm{g} / \mathrm{m}^{2} \cdot \mathrm{d}\right), r_{g 1}=$ rate of ammonia uptake by micro organisms for growth $\left(\mathrm{g} / \mathrm{m}^{2} \cdot \mathrm{d}\right), r_{\text {reg }}=$ rate of ammonia regeneration $\left(\mathrm{g} / \mathrm{m}^{2} \cdot \mathrm{d}\right), r_{v}=$ rate of ammonia volatilization $\left(\mathrm{g} / \mathrm{m}^{2} \cdot \mathrm{d}\right)$.

$$
\frac{\mathrm{d}\left(\mathrm{NO}_{3-} \mathrm{N}\right)}{\mathrm{d} t}=\frac{Q_{i}}{A}\left(\mathrm{NO}_{3-} \mathrm{N}\right)_{i}-\frac{Q_{e}}{A}\left(\mathrm{NO}_{3-} \mathrm{N}\right)+r_{n}-r_{d n}-r_{g 2}
$$

where $r_{d n}=$ rate of denitrification of nitrate $\left(\mathrm{g} / \mathrm{m}^{2} \cdot \mathrm{d}\right), r_{g 2}=$ rate of nitrate uptake by micro organisms for growth $\left(\mathrm{g} / \mathrm{m}^{2} \cdot \mathrm{d}\right)$.

Mass balance for nitrogen settled at the bottom (sink-N), was modelled using Equation (5) in which sedimentation and ammonia regeneration processes were considered.

$$
\frac{\mathrm{d}(\text { Sink-N })}{\mathrm{d} t}=r_{s}-r_{\text {reg }}
$$

where $r_{s}=$ settling rate of organic nitrogen in wetland $\left(\mathrm{g} / \mathrm{m}^{2} \cdot \mathrm{d}\right), r_{\text {reg }}=$ rate of ammonia regeneration $\left(\mathrm{g} / \mathrm{m}^{2} \cdot \mathrm{d}\right)$.

Denitrification rate was modelled by considering denitrifying bacteria suspended in the wastewater. Dawson and Murphy [33] described the denitrification process to follow the Arrhenius kinetics, which is described by Equation (6).

$$
r_{d n}=\left[\left(D R_{-20}\right) \times \theta_{1}^{(T-20)}\right] \times \mathrm{NO}_{3}
$$

where: $D R_{-20}=$ Denitrification rate constant at $20^{\circ} \mathrm{C}\left(\mathrm{d}^{-1}\right)=0-1.0$ (Bacca and Arnett, 1976) and $\theta_{1}=$ Arrhenius 
constant, ranges from $1.02-1.09$ [34].

\subsubsection{Ammonia Uptake by Microorganisms}

Biomass uptake by autotrophic bacteria involves $\mathrm{NH}_{3}-\mathrm{N}$ or nitrates although ammonia is much preferred [35]. Both algae and bacteria prefer ammonia to nitrates. In this study it was assumed that ammonia must be depleted first before nitrate is consumed. This preferential uptake of ammonia to nitrates is accounted for by use of preference factors $p_{1}$ and $p_{2}$ into the modelling equations. The modelling of ammonia uptake followed the Monod kinetics as illustrated in Equation (7).

$$
r_{g 1}=\left[\left(\mu_{\text {max } \_20}\right) \times \theta^{T-20} \times\left(\frac{\mathrm{NH}_{3 \_} \mathrm{N}}{K_{\mathrm{NH}_{3}}+\mathrm{NH}_{3 \_} \mathrm{N}}\right)\right] \times \mathrm{Org} \_\mathrm{N} \times P_{1}
$$

where $\mu_{\text {max } 20}=$ maximum growth rate of bacteria at $20^{\circ} \mathrm{C}\left(\mathrm{d}^{-1}\right), K_{\mathrm{NH}_{3}}=$ Ammonia uptake half rate saturation constant, $\theta=$ Microorganisms growth temperature coefficient $=1.08-1.10[36]$ and $P_{1}=$ Ammonia uptake preference factor.

\subsubsection{Nitrate Uptake by Microorganisms}

It was assumed that nitrate would be consumed only if all ammonia has been depleted in the system. The Monod kinetic equation for suspended bacteria discussed earlier was combined to give Equation (8) used to model the ammonia uptake by micro-organisms.

$$
r_{2}=\left[\left(\mu_{\text {max } \_20}\right) \times \theta^{T-20} \times\left(\frac{\mathrm{NO}_{3 \_} \mathrm{N}}{K_{\mathrm{NO}_{3}}+\mathrm{NO}_{3} \_\mathrm{N}}\right)\right] \times \mathrm{Org} \_\mathrm{N} \times P_{2}
$$

where $K_{\mathrm{NO}_{3}}=$ Nitrate uptake half saturation constant and $P_{2}=$ Nitrate uptake preference factor.

\subsubsection{Ammonia Regeneration Rate}

The nitrogen settled in wetland due to sedimentation process taking place in the system eventually is regenerated back to ammonia. Bigambo [37] described the regeneration process to follow first order kinetics, which is described by Equation (9).

$$
r_{\text {reg }}=R_{\text {Reg_rate }} \times\left(\operatorname{Sink} \_N\right)
$$

where $R_{\text {eg_rate }}=$ Regeneration rate constant of ammonia $\left(\mathrm{d}^{-1}\right)$ and Sink $N=$ Organic nitrogen settled at the bottom (g/day).

\subsubsection{Sedimentation Rate}

Organic nitrogen, algae and bacteria settle down to form a sediment layer in aquatic systems. Algae and bacteria contain organic nitrogen in their body structures in which their deposition to the pond bottom contributes to permanent nitrogen removal. Net loss of settled organic nitrogen due to sedimentation depends on sedimentation rate and regeneration rate. Using Stokes law sedimentation rate in HRP was modelled based on Equation (10).

$$
r_{s}=\frac{g\left(\rho_{s}-\rho\right) d^{2}}{18 \times \mu \times h}
$$

where $g=$ acceleration due to gravity in $\left(\mathrm{m} \cdot \mathrm{s}^{-2}\right), \rho_{s}=$ density of settling organic nitrogen particle in $\left(\mathrm{kg} \cdot \mathrm{m}^{-3}\right), \rho=$ density of water $\left(\mathrm{kg} \cdot \mathrm{m}^{-3}\right), d=$ diameter of the settling organic nitrogen particle $(\mathrm{m}), \mu=$ coefficient of dynamic viscosity of the fluid $\left(\mathrm{N} \cdot \mathrm{s} \cdot \mathrm{m}^{-2}\right), h=$ depth of HRP $(\mathrm{m})$.

The dynamic viscosity of water varies with temperature in accordance with Equation (11) for temperature above $20^{\circ} \mathrm{C}$. The density of wastewater was assumed to be equal to that of water which is $995.69 \mathrm{~kg} / \mathrm{m}^{3}$ at $30^{\circ} \mathrm{C}$ [36]. Equation (11) was used to determine the viscosity of water in the system because in this study water temperature varied from $25.4^{\circ} \mathrm{C}$ to $32.1^{\circ} \mathrm{C}$.

$$
\log \left(\frac{\mu}{\mu_{20}}\right)=\frac{1.3220(T-20)-0.001053(T-20)^{2}}{T+105}
$$




\subsubsection{Ammonia Volatilization Rate}

Factors influencing volatilization of ammonia are temperature and $\mathrm{pH}$. Ammonia in fluids exist in two forms namely ammonium ion, $\mathrm{NH}_{4}^{+}$and dissolved ammonia gas, $\mathrm{NH}_{3}(\mathrm{~g})$. At $20^{\circ} \mathrm{C}$ and a $\mathrm{pH}$ of 9.4 the concentrations of ammonia gas and ammonium ion are equal. At $\mathrm{pH}$ value above $9.4, \mathrm{NH}_{3}(\mathrm{~g})$ is greater and below $\mathrm{pH}$ of 9.4, $\mathrm{NH}_{4}^{+}$dominates. The concentration of ammonia gas is expressed by Equation (12) [31].

$$
\left(\mathrm{NH}_{3}-\mathrm{N}\right)_{\text {Conc }}=\frac{\mathrm{NH}_{3}-\mathrm{N}}{1+10^{(10.05-0.032 T)-\mathrm{pH}}}
$$

The mass transfer of ammonia gas across a liquid interface depends on temperature and the depth of water. The influence of water depth and temperature on ammonia, $\mathrm{NH}_{3}(\mathrm{~g})$, mass transfer coefficient across a liquid is depicted by Equation (13) [31].

$$
K_{l}=\frac{0.056}{d} \exp [0.13(T-20)]
$$

where $K_{l}=$ net convective mass transfer coefficient in liquid phases, $d=$ water depth (m), $T=$ Water temperature $\left({ }^{\circ} \mathrm{C}\right)$.

The combination of Equations (12) and (13) gives ammonia volatilisation rate in the system, which is represented by Equation (14) [31].

$$
\frac{\mathrm{d}\left(\mathrm{NH}_{3}-\mathrm{N}\right)}{\mathrm{d} t}=\frac{0.056}{d} \exp [0.13(T-20)] \times\left[\frac{\mathrm{NH}_{3}-\mathrm{N}}{1+10^{(10.05-0.032 T)-\mathrm{pH}}}\right] \times \mathrm{NH}_{3}-\mathrm{N}_{g}
$$

\subsubsection{Model Calibration and Parameter Optimization}

Stella II water quality modelling software was used in modelling process taking place in the system. Various equations were entered in the model as explained in previous section. The inputs were the daily mean concentration of $\mathrm{NH}_{3}-\mathrm{N}, \mathrm{NO}_{3}-\mathrm{N}$, Org- $\mathrm{N}$ as well as the daily mean temperatures, dissolved oxygen and $\mathrm{pH}$ values. These data were used as inputs to the model during calibration. After calibration, the biofilm activities were set to zero to study the effects of biofilm on nitrogen transformation and removal.

\section{Results and Discussion}

\subsection{Physical-Chemical Parameters}

The temperature of wastewater in the high rate pond varied from an average of $26.7^{\circ} \mathrm{C}$ in the influent to only $26.6^{\circ} \mathrm{C}$ in the effluent with an average standard deviation of 0.6. The temperature variation in HRP was small probably because temperature stratification within a pond is minimal. The temperatures observed in these systems were within optimum ranges for all biological nitrogen transformation reactions such as nitrification, denitrification, mineralization and volatilization processes, which proceed very well in aquatic systems at around $26.5^{\circ} \mathrm{C}$.

Daily variations of $\mathrm{pH}$ within the system ranged between 6.87 and 8.55 with an average value of 7.62 , which was conducive for most of the biological nitrogen transformations processes, except for volatilization which is best at $\mathrm{pH}$ values above 9.4. Daily variations of DO in HRP increased from mean influent concentration of 1.8 $\mathrm{mg} / \mathrm{l}$ to mean effluent concentration of $2.0 \mathrm{mg} / \mathrm{l}$ although in late afternoon hours concentrations in excess of 8 $\mathrm{mg} / \mathrm{l}$ were not uncommon. The increase in oxygen level was largely due to algae photosynthesis which produces oxygen.

\subsection{Nitrate-Nitrogen}

Higher effluent concentration than influents were often observed in HRP indicating that the rate of nitrification was higher than the rate of denitrification. A slight increase of nitrate was observed from an average influent concentration of $1.78 \mathrm{mg} / \mathrm{l}$ to an average effluent concentration of $1.85 \mathrm{mg} / \mathrm{l}$. The small increase in nitrate than expected was probably attributed to short retention time, which was inadequate to allow nitrification process to take place adequately. The minimum retention time recommended for nitrification process in aquatic systems is 8 days (Metcalf and Eddy, 1995), but in this study the retention time of 5 days was used. 


\subsection{Organic-Nitrogen}

The effluent organic nitrogen concentration ranged from $0.56 \mathrm{mg} / \mathrm{l}$ to $8.96 \mathrm{mg} / 1$ with an average value of 4.66 $\mathrm{mg} / \mathrm{l}$. This is equivalent to a decrease of $17.5 \%$ in organic nitrogen concentration from an average influent concentration of $5.65 \mathrm{mg} / \mathrm{l}$, which was attributed to sedimentation process. Shin and Polprasert [35] and later Mayo et al. [38] observed that sedimentation of organic nitrogen contributes significantly to nitrogen removal in aquatic systems. The non-turbulence condition and short depth (about $0.6 \mathrm{~m}$ ) in HRP possibly enhanced sedimentation of organic nitrogen. Another possible cause for the drop in organic nitrogen was mineralization process, which converts organic nitrogen to ammonia.

\subsection{Ammonia-Nitrogen}

Ammonia nitrogen decreased by $34.8 \%$ from an average influent concentration of $15.19 \mathrm{mg} / \mathrm{l}$ to an average effluent concentration of $9.90 \mathrm{mg} / \mathrm{l}$. The reduction was attributed to uptake by micro organisms' (algae and bacteria), and nitrification processes. Ammonia volatilization was unlikely because volatilization is effective at $\mathrm{pH}$ above 9.4 [39], while in this system the $\mathrm{pH}$ ranged from 7.42 to 8.55 . Uptake of ammonia is one of the potential factors reducing ammonia particularly because ammonia is a preferred source of nitrogen than nitrate [31] [40]. Nitrification was another cause of ammonia nitrogen removal since nitrate increased in HRP, which is evident that some ammonia were nitrified to nitrate and hence contributed to the observed decrease of ammonia nitrogen.

\subsection{Total Nitrogen}

Figure 3 shows the variation of influent and effluent of total nitrogen concentration in HRP. Total nitrogen was reduced by $31.7 \%$ from an average of $22.5 \mathrm{mg} / \mathrm{l}$ in the influent to an average of $15.37 \mathrm{mg} / \mathrm{l}$ in effluent of HRP. Significant reduction of total nitrogen was attributed to net loss of organic nitrogen due to sedimentation and uptake of ammonia by micro organisms. Some denitrification may occur even in aerobic conditions because autotrophic ammonia oxidizing bacteria, such as Nitrosomonas europaea and Nitrosomonas eutropha, can also denitrify aerobically under low oxygen concentrations [41].

\subsection{Model Calibration and Simulation}

Table 1 shows values of the constants and parameters obtained from the optimization process. The parameters were optimized by trial and error method, until the best fit between observed and predicted effluent was obtained. The optimized parameters from this study were compared with parameters obtained by other researchers. It was observed that most parameters were within the literature range and close to those obtained by other researchers.

The simulated and observed values for organic nitrogen and ammonia in high rate pond are shown in Figure 4 and Figure 5, respectively. Generally model simulations followed the trend of observed data. The results show that the average percentage removal of total nitrogen between simulated and observed data from the system were close indicating that the model predicted well the nitrogen transformations in the system. It was also found that, the median percentage total nitrogen removal predicted by the model in high rate pond was $30.1 \%$, which

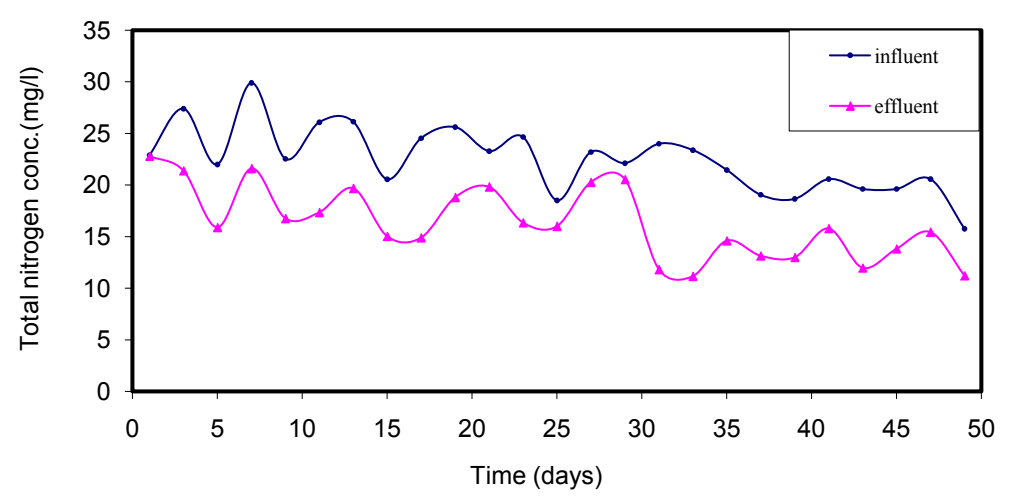

Figure 3. Variation of total nitrogen with time in HRP. 


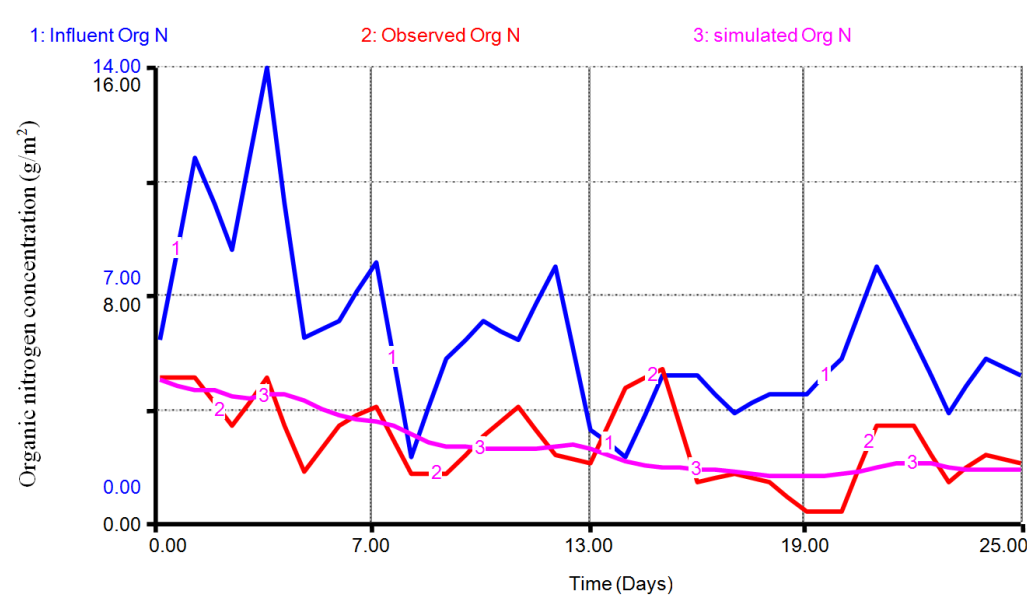

Figure 4. Variation of influent, observed and simulated organic nitrogen in HRP.

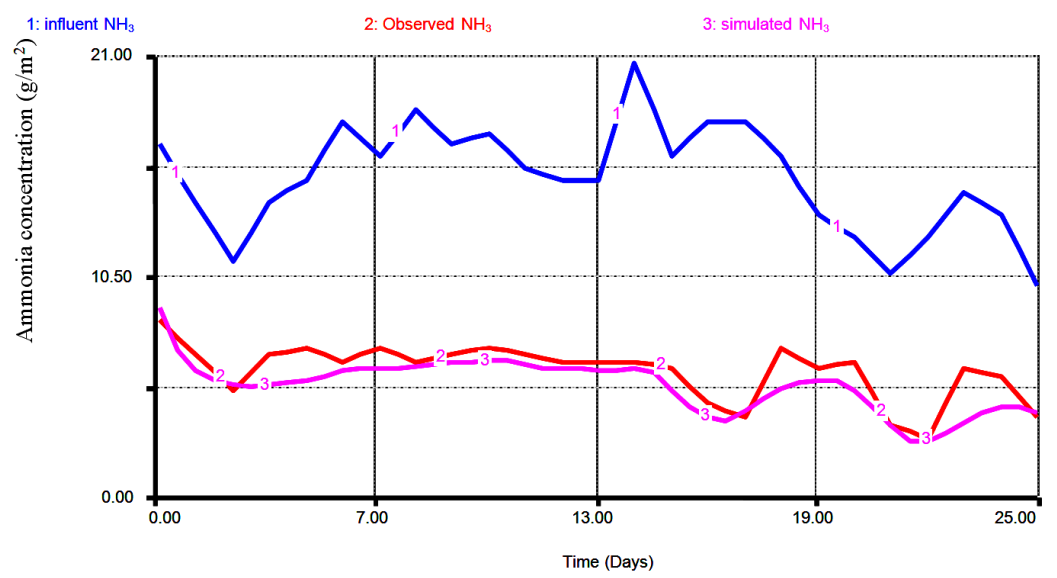

Figure 5. Variation of influent, observed and simulated ammonia nitrogen in HRP.

Table 1. Comparison of model parameter with values available in the literature.

\begin{tabular}{|c|c|c|c|c|c|}
\hline Parameter & Description & Mutamba (2002) & This study & Source & Literature range \\
\hline$\rho_{\mathrm{s} 1}$ & Settling particle density $\left(\mathrm{kg} / \mathrm{m}^{3}\right)$ & 1025 & 1165 & {$[36]$} & $1050-1500$ \\
\hline $\mathrm{D}_{1}$ & Settling particle diameter $(\mathrm{m})$ & $4 \mu \mathrm{m}$ & $1.2 \mu \mathrm{m}$ & {$[42]$} & $0.03-1 \mu \mathrm{m}$ \\
\hline $\mathrm{K}_{\mathrm{N}(1)}$ & Nitrate uptake half saturation constant (mg/l) & 3 & 36 & Optimized & - \\
\hline $\mathrm{K}_{20(1)}$ & Denitrification constant at $20^{\circ} \mathrm{C}\left(\mathrm{d}^{-1}\right)$ & 0.1 & 0.33 & {$[34]$} & $0-1.0$ \\
\hline $\mathrm{u}_{\mathrm{N} 1}$ & Nitrosomonas growth rate $\left(\mathrm{d}^{-1}\right)$ & 1.5 & 1.25 & {$[43]$} & $0.33-2.21$ \\
\hline $\mathrm{Y}_{\mathrm{n} 1}$ & Nitrosomonas yield coefficient (VSS/mgN) & 0.5 & 1.12 & {$[44]$} & $0.03-1.3$ \\
\hline $\mathrm{K}_{\mathrm{fa}}$ & First order reaction constant $\left(\mathrm{d}^{-1}\right)$ & 336.6 & 336.6 & {$[45]$} & 336.6 \\
\hline$\mu_{\max 20(1)}$ & Microorganism growth rate at $20^{\circ} \mathrm{C}$ & 0.1 & 0.18 & {$[46]$} & 0.18 \\
\hline Reg_rate 1 & Ammonia regeneration rate $\left(\mathrm{d}^{-1}\right)$ & & 0.08 & Optimized & \\
\hline Min_rate 1 & Mineralization rate $\left(\mathrm{d}^{-1}\right)$ & 0.002 & 0.14 & {$[30]$} & 0.0005 to 0.143 \\
\hline$\theta_{1}$ & Microorganism growth temperature coefficient $\left(\mathrm{d}^{-1}\right)$ & 1.0 & 1.09 & {$[36]$} & $1.02-1.09$ \\
\hline $\mathrm{K}_{\mathrm{NH}(1)}$ & Ammonia half saturation constant (mg/l) & 56 & 8 & {$[47]$} & $0.32-56$ \\
\hline $\mathrm{K}_{\mathrm{NO}(1)}$ & $\mathrm{O}_{2}$ nitrosomonas half saturation coefficient $(\mathrm{mg} / \mathrm{l})$ & 1.5 & 1.3 & {$[44]$} & $0.13-1.3$ \\
\hline
\end{tabular}


compares closely to those of observed values of $31.7 \%$. Therefore, from the model results it can be concluded that the model sufficiently simulated nitrogen transformation mechanisms in the pilot plant.

Figure 6 shows that $0.24 \mathrm{gN} / \mathrm{m}^{2} \cdot \mathrm{d}$ of organic nitrogen settled to the bottom of HRP, but $0.15 \mathrm{gN} / \mathrm{m}^{2} \cdot \mathrm{d}$ of settled organic-nitrogen was regenerated back to water phase as ammonia due to decomposition of organic nitrogen. Therefore $0.09 \mathrm{gN} / \mathrm{m}^{2} \cdot \mathrm{d}$ of organic nitrogen was permanently removed as net sedimentation. About 0.95 $\mathrm{gN} / \mathrm{m}^{2} \cdot \mathrm{d}$ of ammonia was transformed by nitrification process to nitrate while, denitrification and ammonia volatilization processes contributed to permanent removal in HRP by $0.87 \mathrm{gN} / \mathrm{m}^{2} \cdot \mathrm{d}$, and $0.30 \mathrm{gN} / \mathrm{m}^{2} \mathrm{~d}$ respectively. However, mineralization process and ammonia uptake by micro-organisms were $0.37 \mathrm{gN} / \mathrm{m}^{2} \cdot \mathrm{d}$ and $0.34 \mathrm{gN} / \mathrm{m}^{2} \mathrm{~d}$, respectively.

Figure 7 summarizes the contribution of each nitrogen transformation mechanism in pond. It was evident that the dominant transformation mechanism in the HRP accounting for $29.5 \%$, which is closer to $29 \%$ and $33.0 \%$ reported by [48] [49], respectively. Nitrification was largely favoured by photosynthetic oxygen production by algae as a result of adequate penetration of light in shallow depth HRP. The results also showed that denitrification was the second transformation route contributing $27.0 \%$. In a similar ecological environment [49] observed that denitrification transformed $29.5 \%$ of the total nitrogen transformed in the system. Ammonia uptake by microorganisms was $10.5 \%$, which is falls between a figure of $11 \%$ reported by [48] and $8 \%$ reported by [49]. Ammonia regeneration accounted for $4.7 \%$, while mineralization, volatilization and sedimentation contributed $11.5 \%, 9.3 \%$ and $7.5 \%$ of total nitrogen transformed, respectively. The contribution of volatilization of ammonia was relatively low because of relatively low average $\mathrm{pH}$ of 7.6, which does not encourage ammonia stripping.

Further analysis revealed that, in HRP, denitrification process removed $27.4 \%$, net sedimentation $2.8 \%$ and volatilization removed $9.5 \%$ of the total influent nitrogen. Permanent nitrogen removal from these systems was due to denitrification, net sedimentation and volatilization. Other processes transformed nitrogen into other forms having potential to pollute receiving waters. Figure 8 shows percentage contribution for permanent ni-

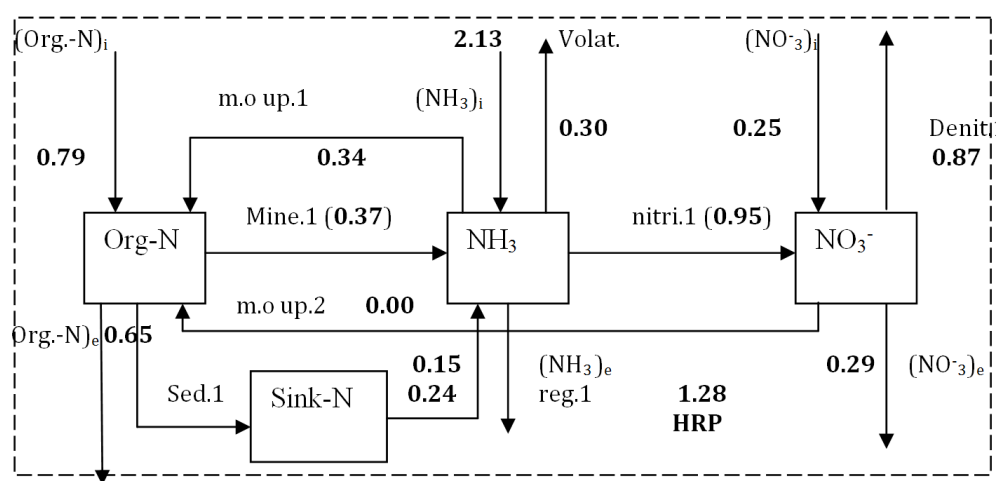

Figure 6. Mass balance diagram for Nitrogen transformation in high rate pond.

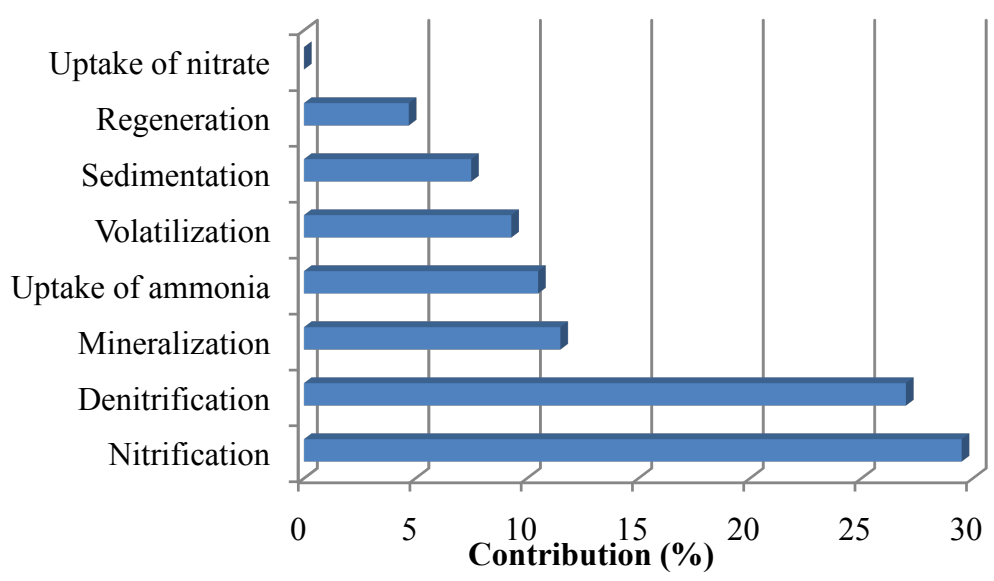

Figure 7. Contribution of various mechanisms on nitrogen transformation. 


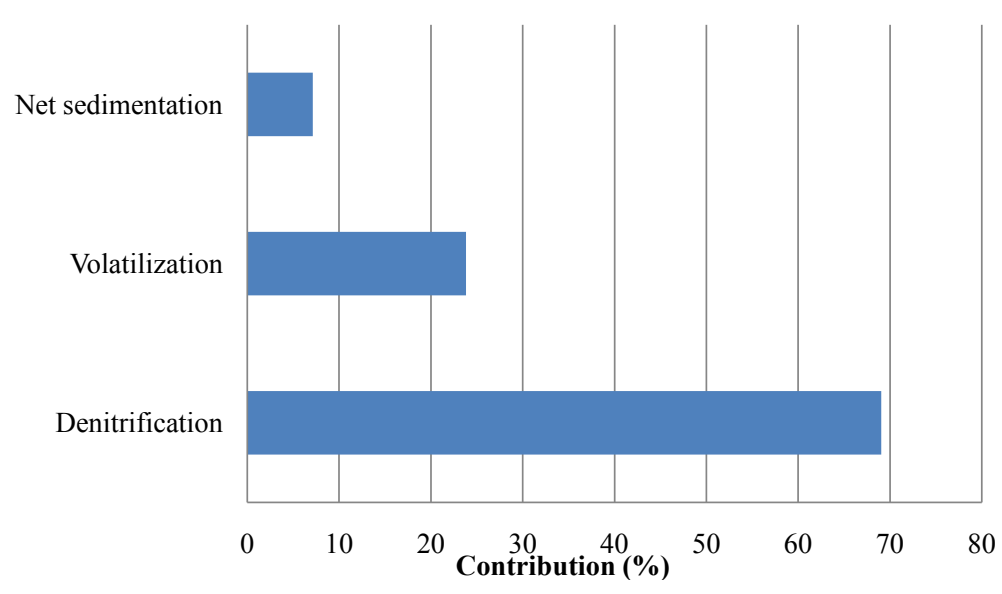

Figure 8. Major permanent nitrogen removal mechanisms and their contribution in HRP.

trogen removal mechanisms in HRP. The major nitrogen transformations which were permanent removal mechanisms from the HRP were denitrification, net sedimentation and volatilization. Denitrification process contributed $69.1 \%$, net sedimentation $7.1 \%$ and volatilization contributed $23.8 \%$ of the total permanent removal mechanisms in HRP. The contribution of net sedimentation of $7.1 \%$ to the total permanent nitrogen removal is substantial bearing in mind that in field scale secondary facultative ponds and maturation ponds, the contribution of sedimentation is less than 3.3\% [2]. Better sedimentation rate in high rate pond was probably contributed by its shallow depth and better quiescence condition as a result of its small surface area. It is worth mentioning that wind induced agitation is less effective in a small HRP water body of $10.2 \mathrm{~m}^{2}$ compared to mid-pond surface areas of $1425 \mathrm{~m}^{2}$ in maturation pond and $2100 \mathrm{~m}^{2}$ in secondary facultative ponds.

\subsection{Model Applications and Limitations}

The developed model can be used to estimate the nitrogen removal in water hyacinth wetland. The ability of the model to simulate the observed trends of nitrogen transformation and removal processes and determine the permanent nitrogen removal in the system, proves that the model can be used as an operation and management tool for existing systems and to design similar systems. Given all input data such as ammonia, nitrate, organic nitrogen as well as daily mean temperatures, dissolved oxygen and $\mathrm{pH}$, the design of a plant capable of achieving the desired nitrogen removal can be obtained by proper model simulation. However, there were small variations between model simulated with observed data, which was attributed to higher fluctuation of observed data due to short period of sample collection while the system was in the stage of stabilizing.

\section{Conclusions}

From these findings the following conclusions are made:

a) The dominant nitrogen transformation processes in HRP were nitrification and denitrification, which transformed 0.95 and $0.87 \mathrm{gN} / \mathrm{m}^{2} \cdot \mathrm{d}$, respectively. These were followed by mineralization $\left(0.37 \mathrm{gN} / \mathrm{m}^{2} \cdot \mathrm{d}\right)$, ammonia uptake by microorganisms $\left(0.34 \mathrm{gN} / \mathrm{m}^{2} \cdot \mathrm{d}\right)$, volatilization $\left(0.30 \mathrm{gN} / \mathrm{m}^{2} \cdot \mathrm{d}\right)$, sedimentation $\left(0.24 \mathrm{gN} / \mathrm{m}^{2} \cdot \mathrm{d}\right)$, and regeneration $\left(0.15 \mathrm{gN} / \mathrm{m}^{2} \cdot \mathrm{d}\right)$. Uptake of nitrate was not observed because of microorganisms' preference for ammonia, which was abundant.

b) The major nitrogen transformation mechanisms in high rate pond were denitrification, net sedimentation and volatilization, which accounted for $69.1 \%, 7.1 \%$ and $23.8 \%$ of the total permanent removal mechanisms in HRP.

\section{References}

[1] Mara, D. (2005) Pond Process Design-A Practical Guide. In: Shilton, A., Ed., Pond Treatment Technology, IWA Publishing, London, 168-187.

[2] Mayo, A.W. (2013) Nitrogen Mass Balance in Waste Stabilization Ponds at the University of Dar es Salaam, Tanzania. 
African Journal of Environmental Science and Technology, 7, 836-845.

[3] Rockne, K.J. and Brezonik, P.L. (2006) Nutrient Removal in a Cold-Region Wastewater Stabilization Pond: Importance of Ammonia Volatilization. Journal of Environmental Engineering, 132, 451-459. http://dx.doi.org/10.1061/(ASCE)0733-9372(2006)132:4(451)

[4] Krkosek, W.H., Ragush, C., Boutilier, L., Sinclair, A., Krumhansl, K., Gagnon, G.A., Jamieson, R.C. and Lam, B. (2012) Treatment Performance of Wastewater Stabilization Ponds in Canada's Far North. Cold Regions Engineering, 612-622.

[5] Faleschini, M., Esteves, J.L. and Camargo Valero, M.A. (2012) The Effects of Hydraulic and Organic Loadings on the Performance of a Full-Scale Facultative Pond in a Temperate Climate Region (Argentine Patagonia). Water, Air and Soil Pollution, 223, 2483-2493. http://dx.doi.org/10.1007/s11270-011-1041-0

[6] Hanai, E. (2006) Nitrogen Transformation in a Coupled High Rate-Water Hyancinths Ponds. Masters of Integrated Environmental Management Dissertation, Department of Chemical and Process Engineering, University of Dar es Salaam, Tanzania.

[7] Tadesse, I., Green, F.B. and Puhakka, J.A. (2004) Seasonal and Diurnal Variations of Pond Temperature, pH and Dissolved Oxygen in Advanced Integrated Wastewater Pond Systems Treating Tannery Effluent. Water Research, 38, 645-654. http://dx.doi.org/10.1016/j.watres.2003.10.006

[8] Al-Sa'ed, R. (2007) Sustainability of Natural and Mechanized Aerated Ponds for Domestic and Municipal Wastewater in Palestine. Water International, 32, 310-324. http://dx.doi.org/10.1080/02508060708692209

[9] Sedlak, R. (1991) Phosphorus and Nitrogen Removal from Municipal Wastewater: Principles and Practice. 2nd Edition, Lewis Publisher, New York, xiii, 224p.

[10] Zimmo, O., van der Steen, N. and Gijzen, H. (2005) Effects of Organic Surface Load on Process Performance of Pilot-Scale Algae and Duck-Weed Waste Stabilization Ponds. Journal of Environmental Engineering, 131, 587-594. http://dx.doi.org/10.1061/(ASCE)0733-9372(2005)131:4(587)

[11] Mugasa, T.B.B. (2005) Removal of Organic Carbon in Water Hyacinths Constructed Wetlands. Masters of Integrated Environmental Management Dissertation, Department of Chemical and Process Engineering, University of Dar es Salaam, Tanzania.

[12] Barrie, A. (2002) Modelling COD Removal in Water Hyacinth Constructed Wetland, MSc Dissertation, Department of Water Resources Engineering, University of Dar es Salaam, Tanzania.

[13] Mayo, A.W. (1995) Modeling Coliform Mortality in Waste Stabilization Ponds. Journal of the Environmental Engineering Division, American Society of Civil Engineers, 121, 140-152. http://dx.doi.org/10.1061/(ASCE)0733-9372(1995)121:2(140)

[14] Osman, B. (1998) Modelling bacterial Removal in Waste Stabilization Ponds in Tropical Climates, MSc (Eng) dissertation, Department of Civil Engineering, University of Dar es Salaam, Tanzania.

[15] Kalibbala, M. (2001) Influence of Water Hyacinth on the Presence of Pathogens in Wastewater Ponds, MSc (Water Resources Eng) Dissertation, Department of Water Resources Engineering, University of Dar es Salaam, Tanzania.

[16] Alahmady, K., Stevens, K., Atkinson, S. (2013) Effects of Hydraulic Detention Time, Water Depth and Duration of Operation on Nitrogen and Phosphorus Removal in a Flow-Through Duckweed Bioremediation System. Journal of Environmental Engineering, 139, 160-166. http://dx.doi.org/10.1061/(ASCE)EE.1943-7870.0000627

[17] Shilton, A. and Walmsley, N. (2005) Introduction to Pond Treatment Technology. In: Shilton, A., Ed., Pond Treatment Technology, IWA Publishing, London, 1-13.

[18] Isosaari, P., Hermanowicz, S.W. and Rubin, Y. (2010) Sustainable Natural Systems for Treatment and Disposal of Food Processing Wastewater. Critical Reviews in Environmental Science and Technology, 40, 662-697. http://dx.doi.org/10.1080/10643380802359396

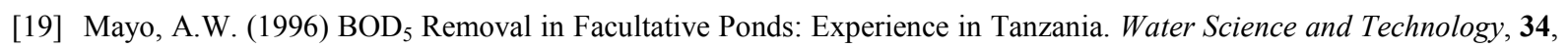
107-117. http://dx.doi.org/10.1016/S0273-1223(96)00827-X

[20] Vera, I., Sáez, K. and Vidal, G. (2013) Performance of 14 full-Scale Sewage Treatment Plants: Comparison between Four Aerobic Technologies Regarding Effluent Quality, Sludge Production and Energy Consumption. Environmental Technology, 34, 2267-2275. http://dx.doi.org/10.1080/09593330.2013.765921

[21] Halling-Sørensen, B. and Jørgensen, S.E. (1993) The Removal of Nitrogen Compounds from Wastewater, Elsevier, London.

[22] Showers, W.J., Williams, C.M. and Jennings, G.D. (2006) Impact of Large Poultry Operations on Groundwater: Stable ${ }^{15} \mathrm{~N}$ Isotopes of Nitrate Assessment. International Journal of Poultry Science, 5, 318-329. http://dx.doi.org/10.3923/ijps.2006.318.329

[23] (2013) http://ammoniabmp.colostate.edu 
[24] Kelter, P.B., Grundman, J., Hage, D. and Carr, J.D. (1997) A Discussion of Water Pollution in the U.S. and Mexico; With High School Laboratory Activities for Analysis of Lead, Atrazine and Nitrate. Journal of Chemical Education, 74, 1413-1421. http://dx.doi.org/10.1021/ed074p1413

[25] Konig, A., Pearson, H.W. and Silva, S.A. (1987) Ammonia Toxicity to Algae Growth in Waste Stabilization Ponds. Water Science and Technology, 19, 115-122.

[26] Orji, J.C., Nweke, C.O., Nwabueze, R.N., Anyanwu, B.N., Chigbo, L.O. and Nwanyanwu, C.E. (2011) Effect of Abattoir Wastes on Ammonium and Nitrite Consumptions in a Tropical Fress Water Ecosystem. Journal of Environmental Science and Technology, 4, 590-600. http://dx.doi.org/10.3923/jest.2011.590.600

[27] Senzia, M.A. (2003) Modelling of Nitrogen Transformation and Removal in Subsurface Flow Constructed Wetlands during Treatment of Domestic Wastewater. Ph.D. Thesis, Department of Water Resources Engineering, University of Dar es Salaam, Dar es Salaam.

[28] Mayo, A.W. (1989) Effect of Pond Depth on Bacterial Mortality Rate. Journal of Environmental Engineering, 115, 964-977. http://dx.doi.org/10.1061/(ASCE)0733-9372(1989)115:5(964)

[29] (2012) Standard Methods for the Examination of Water and Wastewater. 22nd Edition, American Public Health Association, American Water Works Association, Water Pollution Control Federation.

[30] Martin, J.F. and Reddy, K.R. (1997) Interaction and Spatial Distribution of Wetland Nitrogen Processes. Ecological Modeling, 105, 1-21. http://dx.doi.org/10.1016/S0304-3800(97)00122-1

[31] Fritz, J.J., Middleton, A.C. and Meredith, D.D. (1979) Dynamic Process Modelling of Wastewater Stabilization Ponds. Journal of the Water Pollution Control Federation, 51, 2724-2743.

[32] Mayo, A.W. and Bigambo, T. (2005) Nitrogen Transformation in Horizontal Surface Flow Constructed Wetland I: Model Development. Physics and Chemistry of the Earth, Parts $A / B / C, 30,658-667$. http://dx.doi.org/10.1016/j.pce.2005.08.005

[33] Dawson, R.W. and Murphy, K.L. (1972) The Temperature Dependency of Biological Denitrification. Water Research, 6, 71-83. http://dx.doi.org/10.1016/0043-1354(72)90174-1

[34] Bacca, R.G. and Arnett, R.C. (1976) A Limnological Model for Eutrophic Lakes and Impoundment. Battele, Inc., Pacific Northwest Laboratories, Richland, 89-95.

[35] Shin, H.K. and Polprasert, C. (1988) Ammonia Nitrogen Removal in Attached-Growth Ponds. Journal of Environmental Engineering, 114, 846-863. http://dx.doi.org/10.1061/(ASCE)0733-9372(1988)114:4(846)

[36] Metcalf and Eddy, Inc. (1995) Wastewater Engineering: Treatment, Disposal and Reuse. McGraw-Hill Ltd., New Delhi.

[37] Bigambo, T. (2003) The Effects of Biofilm Activities on Nitrogen Transformation in Horizontal Subsurface Flow Constructed Wetlands. M.Sc. Thesis, Department Water Resources Engineering, University of Dar es Salaam, Dar es Salaam.

[38] Mayo, A.W., Muraza, M. and Norbert, J. (2013) The Role of Mara River Basin Wetland in Reduction of Nitrogen Load to Lake Victoria. International Journal of Water Resources and Environmental Engineering, 5, 659-669.

[39] Reddy, K.R. and Graetz, D.A. (1987) Carbon and Nitrogen Dynamics in Wetland Soils. In: Hook, D.D. et al., Eds., The Ecology and Management of Wetlands, Springer, Berlin, 307-318.

[40] Neel, J.K., McDermott, J.H. and Monday, C.A. (1961) Experimental Lagoon of Raw Sewage at Fayette, Missouri. Journal of the Water Pollution Control Federation, 33, 603-641.

[41] Helmer, C., Kunst, S., Juretschko, S., Schmid, M.C., Schleifer, K.H. and Wagner, M. (1999) Nitrogen Loss in a Nitrifying Biofilm System. Water Science and Technology, 39, 13-21. http://dx.doi.org/10.1016/S0273-1223(99)00145-6

[42] O’Melia, C.R., Hahn, M.W. and Chen, C.T. (1997) Some Effects of Particle Size in Separation Processes Involving Colloids. Water Science and Technology, 36, 119-126.

[43] Jørgensen, S.E. (1994) Fundamentals of Ecological Modelling: Development in Environmental Modelling. Elsevier Science B.V., Amsterdam.

[44] Charley, R.C., Hoper, D.G. and McLee, A.G. (1980) Nitrification Kinetics in Activated Sludge at Various Temperatures and Dissolved Oxygen Concentrations. Water Research, 14, 1387-1396. http://dx.doi.org/10.1016/0043-1354(80)90002-0

[45] Polprasert, C. and Agarwalla, B.K. (1994) A Facultative Pond Model Incorporating Biofilm Activity. Water Environment Research, 66, 725-732.

[46] Ferrara, R.A. and Hermann, D.P.F. (1980) Dynamic Nutrient Cycle Model for Waste Stabilization Ponds. Journal of the Sanitary Engineering Division, 106, 37-55.

[47] Henze, M. (1991) Capabilities of Biological Nitrogen Removal Processes from Wastewater. Water Science \& Techno- 
$\log y, 23,9-11$.

[48] Mutamba, J. (2002) Nitrogen Removal in a Coupled High Rate Pond (HRP) and Subsurface Gravel Bed Constructed Wetland. M.Sc. Thesis, Department Water of Resources Engineering, University of Dar es Salaam, Dar es Salaam.

[49] Mkama, M. (2005) Effect of Pretreatment on Nitrogen Transformation and Removal in a Sub Surface Gravel Bed Constructed Wetland. M.Sc. Thesis, Department Water of Resources Engineering, University of Dar es Salaam, Dar es Salaam. 